\title{
Clinical Classification of Hemiplegia and Its Application on Rehabilitation
}

\author{
by
}

Yoshinobu Hirakata M. D.*

from

Department of Physical Therapy and Internal Medicine, Tokyo

University School of Medicine (Chief : Prof. Yoshio OsHIMA)

\begin{abstract}
Classification of hemiplegia has not been accomplished though this disease is very frequent. The clinical picture of hemiplegia presents as uniform appearance from one standpoint but from the other stand point it has many variety of manifestation, in the degree of motor impairment, potentiality of improvement, degree of spasticity and their distribution pattern.

This classification is provided by two fundamental principles, 1) Classify by the localization of lesion when it can be clarified. 2) If it is not clear, classify by the intensity, distribution pattern, and chronological sequence of spasticity.

Thus following eight types are determined.

(A) Type showing spastic posture from early stage

A-1 Rigidity type

A-2 Immediate Wernicke-Mann type

(B) Type showing flaccid posture in early stage

B-1 Delayed Wernicke-Mann type

B-2 Hypotonic type

B-3 Prolonged atonic type

(C) Syndromes that the lesion is clear.

C-1 Ponto-bulbo-cerebellar syndrome

C-2 Thalamo-basal-ganglia syndrome

C-3 Circumscribed cortical syndrome

(D) Unclassified group

Those groups have characteristics respectively, and they are useful for the estimation of prognosis, precaution against complication, and choice of therapeutic procedure.
\end{abstract}




\title{
脳卒中片まひの臨床分類と \\ そのリハビリテーションに括ける応用
}

\author{
平方義 信*
}

\section{緒 論}

脳卒中による片麻瘏は, きわめて頻度の高い疾 患であるにかかわらず，その臨床分類を試みたも のは少ない、リハビリテーションに拈いては，患 者のもつ種々の障害に対して適時に適切な治療を 行ならために,きたりうる運動障害, 共存障害お よび 2 次性障害を予知し, 予後を予測しうる臨床 分類の必要が痛感される。すでに脳性麻痷につい ては Phelps ${ }^{1)}$ 失語症については Schuell'2) その 他がこのような予後と治療に直結した分類を提示 し，これがリハビリテーションの進歩に役だって いるが，片麻痺においては各ケースごとに治療を 行ならことが一般であり，Rusk ${ }^{3)}$ のごときも臨 床分類を試みようとしていない。

脳血管障害の臨床像は, 脳の機構の複雑性, 脳 血管障害の機序およびその局在や広がりの多様 性, 修復機転の個人差などから，きわめて複雑多 様な障害が予想されるにかかわらず，運動障害と しては一様に片麻痺のみが見られ，これがあまり にも著明であるために, 他の共存障害および片麻 痷における detail の差は無視されて，ただ 1 種 のものとして扱われている傾向がある.

しかし多数の片麻㾧を観察していると, 個々の 例によりその様相は大いに異なるものであり，し かもいくつかの類型に分けて扱らべきものである という印象を受ける，著者は片麻痷のリハビリテ ーションの研究に従事し, その病性の分布パタ一 ン, 強度, 時間的経過による変化に興味をもち, これらをパラメーターとして片麻痷を分類し，興

* 東大医学部物療内科
味ある知見をえたので報告する。

\section{研 究 史}

脳卒中の臨床分類を試みた文献は国内にも国外 にもない.わずかに Brunnstrom4) が 1967 年に 行なった, 回復段階テストについて, これが分類 に役だつことを述べているが，明確な型として分 類したものではない.

Treanor ${ }^{5)}$, Twitchel ${ }^{6,7)}$, Hasting8) らの片麻 盘の回復過程についての記載もあるが，いずれも 片麻疩全体を 1 つのカテゴリーに属するものとし て扱っている。

ただ, Pesczynski9,10)のみは, 片麻㾇に種々 の程度, 型のものがあり, 特に遷延する弛緩性を 示すものは治療に抵抗して治りにくいことを述べ ているが，具体的な分類を提示していない．

主観的に片麻瘦を驰緩性と㾏性に分けることは 今日までしばしば行なわれている。たとえば New York 大学の Rehabilitation Monograph (1952) のごとく，片麻痷をこの 2 つの群に分け た後, それぞれを完全麻痺と不完全麻痷に細分し ているが，その定義は述べられておらず，分類と

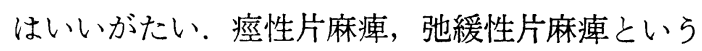
分け方は，これのみでなく，枚挙にいとまがない ほどである。病性という観念には混乱があり，神 経生理学的には個々の筋の属性であるべき性質で あって, 全身的現象の形容に用いるところに無理 があるものと考劣られる。その記載の中には痮性 と, その 2 次的結果である筋緊張ないし真性短縮 との混同があり, 㾏性の分布パターンと強弱, 経 時的変化について考慮されていない，㾏性という 概念については, その後も Granit'11), Yahr \& 


\begin{tabular}{|c|c|c|}
\hline 型または症候群 & 定義および基準 & 除 外 基 準 \\
\hline $\begin{array}{l}\text { 橋延髄小脳症候群 } \\
(\mathrm{C}-1)\end{array}$ & $\begin{array}{l}\text { 交攴性, または交代性片麻疾, 小脳症状を伴うことも伴わない } \\
\text { こともあ. }\end{array}$ & \\
\hline $\begin{array}{l}\text { 視床基底核症候群 } \\
(\mathrm{C}-2)\end{array}$ & 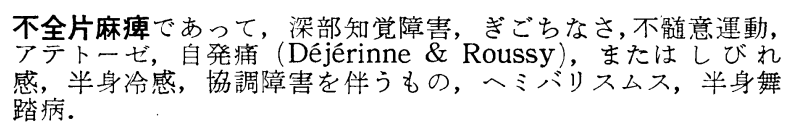 & 完全片麻痺は除外 \\
\hline $\begin{array}{l}\text { 限局性皮質症候群 } \\
\qquad(\mathrm{C}-3)\end{array}$ & $\begin{array}{l}\text { 純粋失語 (失読, 失畫, 失認を含む), 純粋 Gerstmann 症候 } \\
\text { 群, 明らかな皮質病单の認められる単麻痺. 一時的に片麻痺は } \\
\text { あってもよい. }\end{array}$ & 永久片麻痺 \\
\hline$\frac{\text { 強剛型 }}{(\mathrm{A}-2)}$ & $\begin{array}{l}\text { 誇張された上肢屈筋, 下肢伸筋の拘・縮初期からこの姿勢を示 } \\
\text { し, 矯正することは困難. }\end{array}$ & \\
\hline $\begin{array}{l}\text { 即時 Wernicke-Mann 型 } \\
(\mathrm{A}-2)\end{array}$ & 発作初期からの Wernicke-Mann 姿勢, 矯正は容易である. & 強い拘縮は弱剛型 \\
\hline $\begin{array}{l}\text { 遅延 Wernicke-Mann 型 } \\
\qquad(\mathrm{B}-1)\end{array}$ & $\begin{array}{l}\text { 初期は低緊張,しかししだいに懸張を増し発作後 3-6か月で定 } \\
\text { 型的な Wernicke-Mann 姿勢をきたす. }\end{array}$ & \\
\hline $\begin{array}{l}\text { 低緊張型 } \\
(\mathrm{B}-2)\end{array}$ & $\begin{array}{l}\text { 全体的な低緊張, 軽い痤性は部分的に存在する, 手, 指には骨 } \\
\text { 関節症に由来する拘縮ないし強直の存在することもある。 }\end{array}$ & \\
\hline $\begin{array}{l}\text { 遷延無緊張型 } \\
(\mathrm{B}-3)\end{array}$ & $\begin{array}{l}\text { 全部に広がる重症, かつ遷延する弛緩性筋力に改善見られず } \\
\text { ( } 3 \text { かの試行後, ただし大腿四頭筋, 腸腰筋, 下煺三頭笳の } \\
\text { わずかな改善は見られることもあるす). }\end{array}$ & \\
\hline $\begin{array}{l}\text { 分類不能群 } \\
\text { (D) }\end{array}$ & 以上のいずれにも属しない. & \\
\hline
\end{tabular}

Purpura ${ }^{12)}$ の総説があるが，片麻瘏 の 分類に利 用しらる研究はない.

一方脳の損傷部位と麻舫および痙性の出現につ いては, 実験生理学の方面と, 臨床においての脑 血管写を中心とした業績とが多数に存在する. 特 に脳幹部病変と強剛怙よび不随意運動についての Cooper の研究 ${ }^{13)}$, Costa \& Yahr ${ }^{14)}$ の基底核 病変についての研究は, 定位脳手術による知見, Levo DOPA の応用之相伴って, この領 域にお ける病変と症状の相関を明らかにした。 また後シ ナプス興奮性電位についての研究は各国で競って 行なわれ, 痤性発現の機序にアプローチしつつあ るが，そのまま脳卒中の臨床分類とは関連づけら れない。

運動野, 前運動野病巣については, Kennard \& Fulton ${ }^{15)}$, 以来多数の業績があり, 側頭葉, 頭頂葉についても Critchley ${ }^{16)}$ の明快な観察を はじめとして，わが国でも大橋17)，井村18) らの 観察はすぐれたものであるが，身体症状との相関 はとらえられていない。

臨床面では相沢, 後藤ら ${ }^{19)}$, おょび亀山, 大友
らの脳循環, 動脈閉塞と臨床症状との相関, 臨床 症状と解剖病変との対比は重要な価值をもってい る。また花籠20) の脳血管写所見とリハビリテー ションの予後についての研究も臨床的意義が大き いが，一般臨床に直ちに利用しえない点では，脳 血管写という技術的制約を感じざるを得ない。

Scheinker は内包出血を Mesial と Lateral の 2 型に分けて，予後にかなりの差があることを示 しているが，急性期における問題であるので，本 研究の主題とは関連が少ない，以上のように患者 の臨床像から片麻痖の分類を試みた研究はないよ うである。

著者は昭和 37 年夏から現在にいたるまで，片 麻痺のリハビリテーションに従事しているが，そ の初期において, 片麻疸の筋緊張が，全く無緊張 のものから, 著しく緊張が強くて, 強直ではない にもかかわらず屈曲もしくは伸展せしめるのに時 間をかけてきわめて強い力を作用せしめなければ ならない例まで，広い範囲の個体差があることを 知り, さらにその治瘾過程にも, 合併障害にも特 定な相関があって，ある程度層別できるのではな 


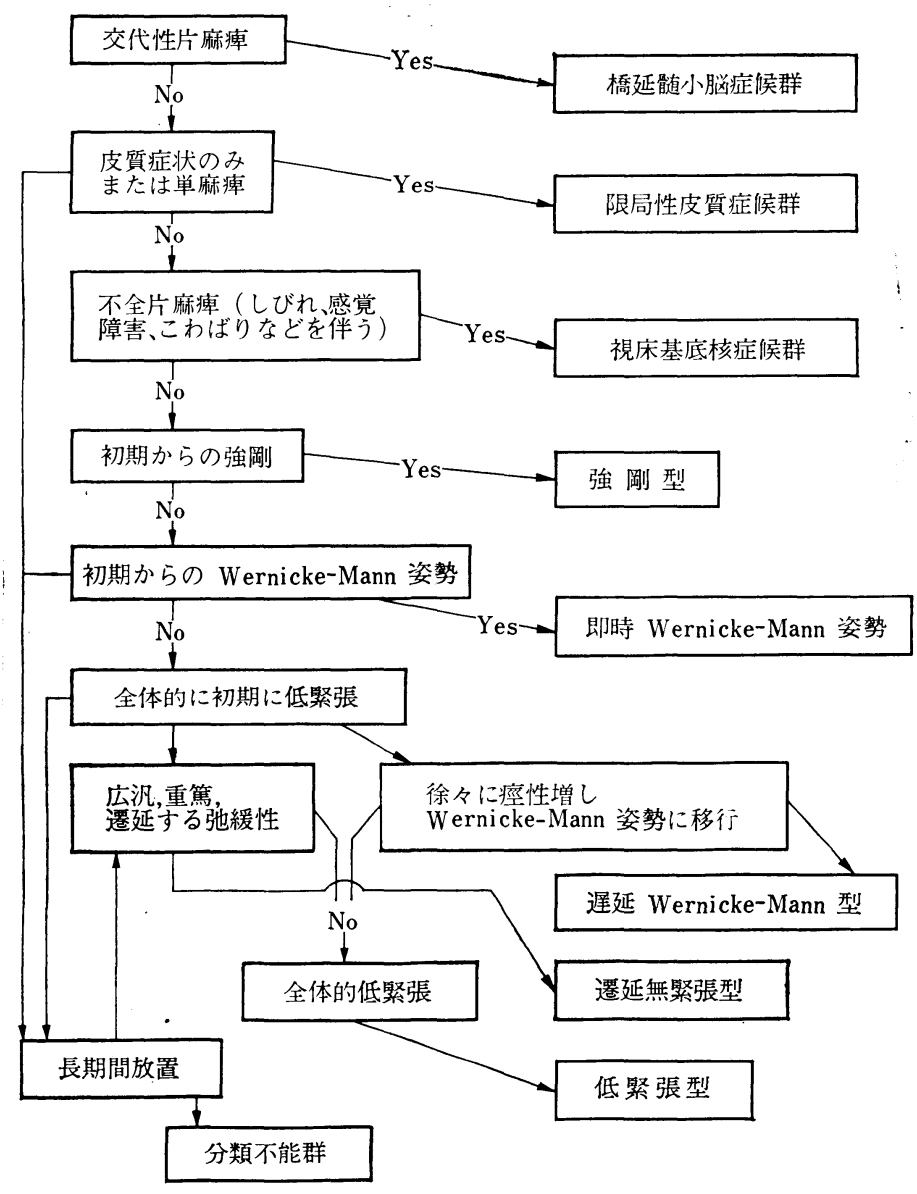

Diagram 1

いか，という感じをもったしかし WernickeMann の好発姿勢という表現型をもった片麻瘏 を 1 群として取り扱っているらちに，この群は初 期は弛緩性でしだいに痓性の増悪によりこの姿勢 になったものと, 初期から強制姿勢としてこの型 をとっているものがあることに気ついた，さらに 後者は容易に徒手で矯正でき，矯正できた位置で は各筋の随意性が認められるものと, 上肢の屈 筋，下肢の伸筋の著しい筋緊張のみ，誇張された Wernicke-Mann 姿勢を示し，筋力としては注 とんどゼロに近いものとの 2 群に分れることを認 めた。これを糸口として, ‘発作初期の病型' と “現在の病型” の 2 つ病型を双方考慮した分類を 試みたのが本研究である.

この分類においては，2つの原則を基本とし た。すなわち，
1）病巣の明確なものは病巣によっ て区分する.

2) 病巣の明確でないものは, 痙性 の分布，強度，時間による変化 をパラメーターとして区分す る.

という 2 原則である。これは臨床分類 の実用性を重視したためであって，病 巣と痤性との関係を明確にする努力が なされるべきであるが，治療のための 分類としては意義があると考える。こ れにより，基準表，および Diagram を作り，分類する基礎とした。

\section{研究の対象と方法}

脳卒中による片麻瘴をきたして長野 県厚生連鹿教湯温泉療養所, 温泉治療 研究所, 甲州中央温泉病院に入院した 発病直後から 1 年 6 か月まで（一部に それ以上経過したものを含む）の患者 277 例を選んだ。これらには糖尿病, 梅毒等の他種の Neuropathy の合併 の可能性あるもの, 両側性片麻㾴を除 外した.

すべての患者にリハビリテーショ ンを施行しつつ, 経時的に 1 か月間隔 で筋力, 関節可動域, 日常生活動作, 装具の必要 性などを評価し，一方で基準表（表 1 ）により， Diagram 1, Diagram 2 を使用して各群への選 別を行なった。

これらの各群について, 㽷性の定性的および定 量的観察を行なったが，前者は Wartenberg の 方法により，後者は膝腱反射の閾值を浦本式間值 測定機により数回測定し，最小值を求めた。

筋力については, 拮抗筋の病性, 協同パターン などに十分留意してその影響を避けつつ Daniels の 6 段階法により測定した。なおこの際B Brunnstrom の回復段階も同時に測定し参考にした. 被検筋は患側および健側のすべての筋であるが， 上肢については肩甲帯筋, 伸筋群, 屈筋群の 3 群 に分け，各型において十分な治療をした後の回復 した筋力の平均および標準偏差を計算した。下肢 


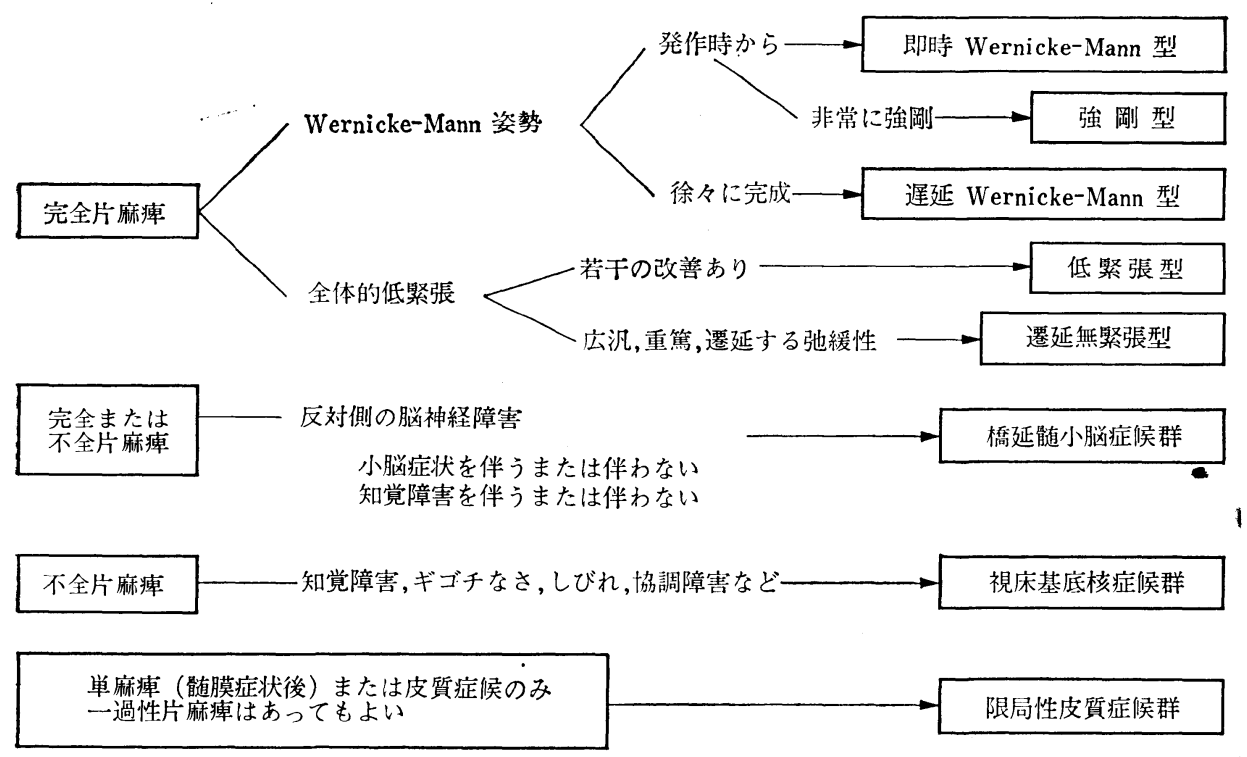

\section{Diagram 2}

表 2 原因疾患別型別頻度（臨床症状による）

\begin{tabular}{|c|c|c|c|c|c|c|}
\hline 型 & 脳出血 & 脳塞栓 & 脳血栓 & くも膜下出血 & 不 明 & 総 \\
\hline 橋延髄小脳症候群 & & & & & 3 & 3 \\
\hline 視床基底核症候群 & 3 & & 12 & & 3 & 18 \\
\hline 限局性皮質症候群 & & & 1 & 2 & 1 & 4 \\
\hline 強剛型 & 6 & & 3 & & & 9 \\
\hline 即時 Wernicke-Mann 型 & 25 & 1 & 11 & & 11 & 48 \\
\hline 遅延 Wernicke-Mann 型 & 2 & 1 & 8 & 2 & & 13 \\
\hline 低緊張型 ～～～～～～～ & 9 & 5 & 113 & 9 & 1 & 137 \\
\hline 遷延無緊張型 & & & 7 & & & 7 \\
\hline 計 & 45 & 7 & 155 & 13 & 19 & 239 \\
\hline
\end{tabular}

そおいては真性短縮その他の 2 次的影響を受けぬ よう，代表として大腿四頭筋を選び，各型の間で 治療開始時の平均值を比較した。

予後の測定については, 入院時歩行不能であっ た者のみを対象とし, 最終段階においてなんらか の補助具を必要としたものはこれを注記し, 安定 な歩行に至るまでの期間を月数で表わした.

共存障害については, 失語は Schuell の分類 により, 失認はスクリーニングテストによって要 検查者を発見したのち精検し，てんかんは明らか な発作を有するものはそれを指標とし，脳波によ って確認した，脳波にのみ異常を認めた例は今回 は除外した。

脳血管写は原因疾患について特に追求を要する もの, 病巣部位の確定を要するものについて行な
い, 通常は病巣側の夕, 内頸動脈または前交通動 脈閉塞の疑われる例には両側に行ならた。

筋電図は埋込筋電図により, 28 ミクロンの Karma Wire 2 本を封入した釣針型電極を用 い, 被検筋に刺入したのち, 各種の体位をとら せ，または動作せしめて姿勢による協同反射パタ ーン, 随意運動時の筋活動を検し, 一部は表面電 極も用いた，被検筋は今回は肩甲帯の筋のみにと どまった。すなわち僧帽筋上部，中部，下部，菱 形筋, 前鋸筋, 三角筋前剖, 中部, 後部, 棘上筋, 棘下筋, 大円筋, 小円筋, 肩甲下筋, 上腕三頭筋, 上腕二頭筋である.

\section{検查成績}

1. 型別頻度 

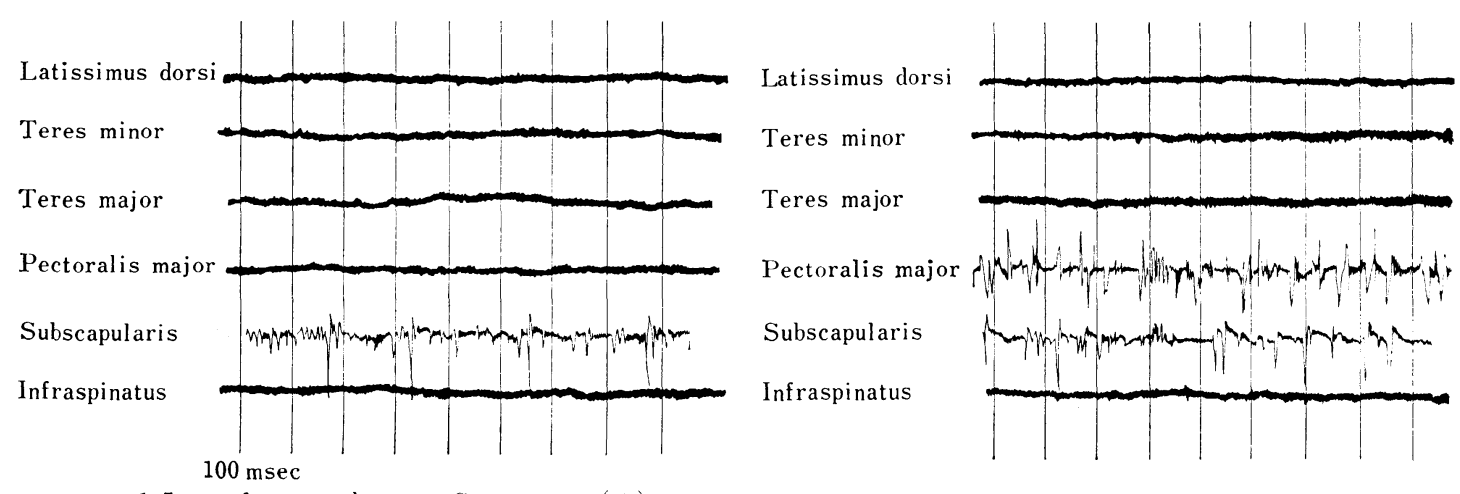

M.A. 1.5 yrs. from stroke

Contracture (it)

図 1 肩甲筋筋電図
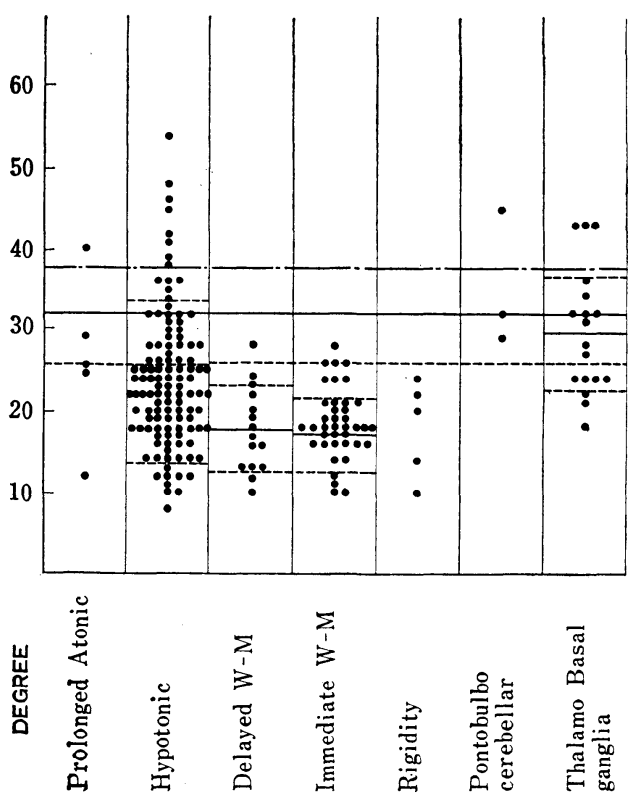

図 2 患者膝反射閾值

矯延髄小脳症候群が 3 例（1.1\%)，視床基底核 症候群が 18 例（6.5\%），限局性皮質症候群が 4 例 (1.4\%), 強剛型が 9 例 (3.4\%), 即時 WernickeMann 型が 46 例 (16.6\%), 遅延 WernickeMann 型が 13 例 (4.8\%), 低緊張型が 160 例 (57\%)，遷延弛緩型が 7 例 $(2.5 \%)$ となってい る. 分類不能群は 27 例 (10\%) である (表 2$)$.

左右差については有意差を認めない.

2. 原因疾患別型別頻度

臨床症状からの推定による 原因疾患別分類 で は, 遅延 Wernicke-Mann 型, 低緊張型, 遷延 無㛑張型の 3 型は脳硬塞によることが圧倒的に多
い。また定義から，限局性皮質症候群はくも膜下 出血によることが $1 / 2$ をめる。視床基底核症候 群に脳血栓と診断されたものが 18 例中 12 例 (66\%) あるが，これは昏睡を伴わなかったため， 文部省脳卒中研究班の基準では脳血栓とせざるを 得なかったが，この点は後に考察する.

3. 埋込筋電図法により, 肩甲諸筋の随意性を 検索し，また可動域と他動的伸張時の筋活動およ び姿勢による変化を即時 Wernicke-Mann 型 3 例, 低緊張型 4 例, 遷延無緊張型 2 例について観 察した。 即時 Wernicke-Mann 型では, すべて。 の筋に随意性の活動電位が見られ，立位時に棘上 筋, 三角筋中部線維からの活動電位が著しく増強 するのが見られた。また低緊張型，遷延無緊張型 では僧帽筋上部線維を除いては随意性はなく，他 動的伸張に際して肩甲下筋からの漸減性の放電が あることが 6 例中 5 例に認められた。

4. 膝反射の閾値を定量的に測定した結果では 次のような事実が認められた（図 1 ).

a.いずれの型においても患側の闘值は低い，ただ し非罪患側を健常と見なすことはできず，しばし ば患側より高くはあるが閥值は低下している場合 がある。

b. 即時 Wernicke-Mann 型では閥值の 低下が著 しく, 健常者が $34.4^{\circ} \pm 4^{\circ}$ であるのに $17.8^{\circ} \pm$ $4.0^{\circ}$ であった. 初発時の外見はこれと著しく異な る遅延 Wernicke-Mann 型も，腱反射閥值は $18.2^{\circ} \pm 4.5^{\circ}$ であり，この㾠性が特異な姿勢を続 発せしめるものであることを示した。低緊張型で も $23.5^{\circ} \pm 7^{\circ}$ であった。

c. 視床基底核症候群では健常人平均值との間に有 

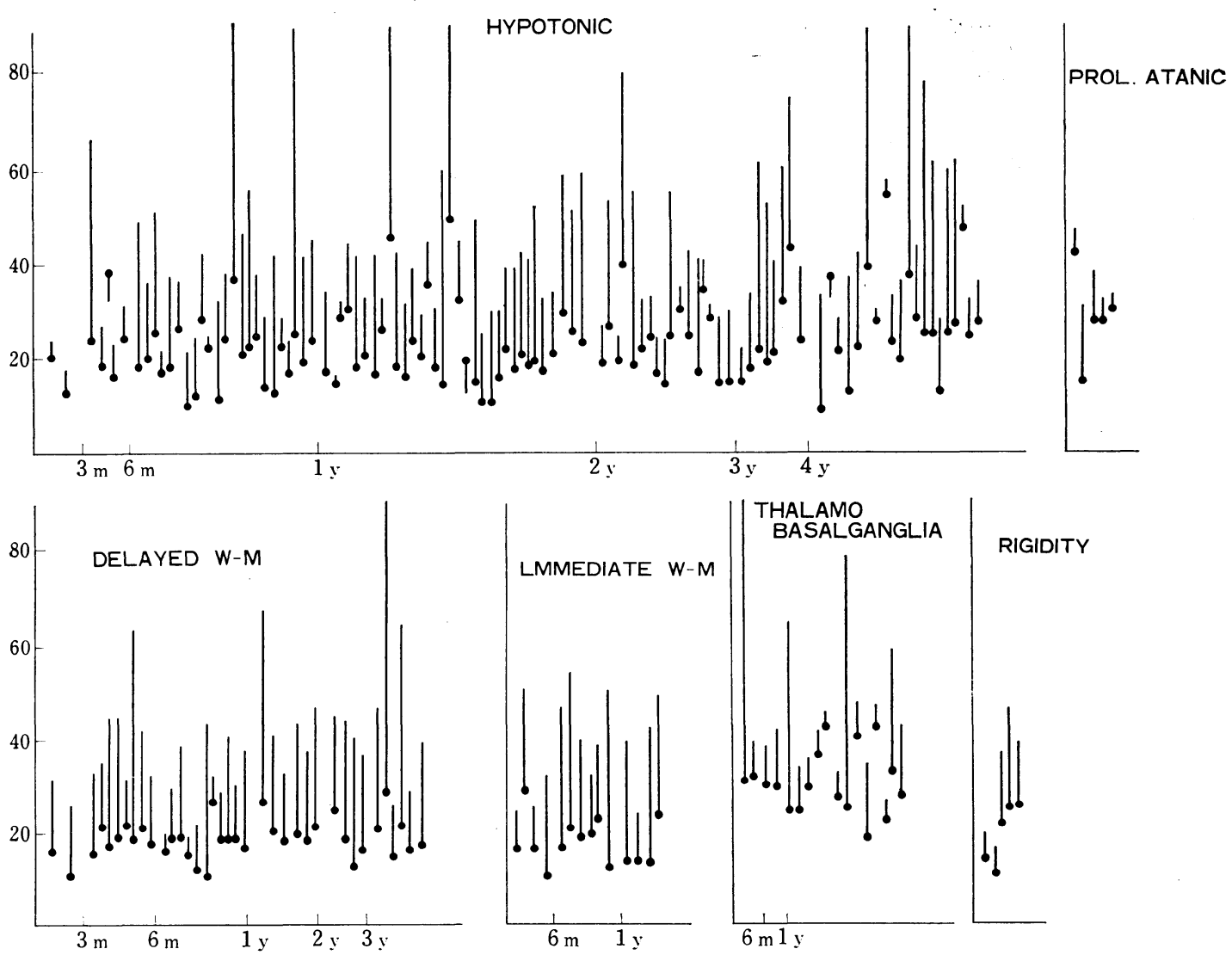

Keys: Dot shows value of involved. line, difference of both side.

図 3 型別経過月別健側および患側膝皮射閾值

意の差は認められない。

d. 強剛型においては即時 Wernicke-Mann 型よ りさらに低い值を示したが，例数が少なく統計的 な結論は得られない.

e . 遷延無緊張型においても，患側腱反射閥值はや や低值を示す.

5. 対象群のほかにきわめて新鮮な例から, 非 常に陳旧な例まで，区分の明確な症例群をとり， 患側と健側を測定したところ図 2 のごとくであっ た。すなわち。

a. 経過月数または年数による変動は各群の間でな い(図 3 ).

b. 各群の特徵は前項で述べた通りである.

c. 即時 Wernicke-Mann 型, 遅延 WernickeMann 型のうちには, 患側と健側の䦭值がともに 低下したものが見られる。

6. 共存障害について, 遷延無緊張型では重篤な 頭頂側頭葉皮質症状が必ず合併していることが目
だつ (表 3 ). すなわち右片麻痺では 4 例中 4 例に Schuell 3 群, もしくは 5 群の失語症を合併し, 左片麻痺 3 例中 3 例に身体図式失認, 左半側空間 失認が認められた。これらのらち，脳血管写を行 なった 3 例ではいずれも中大脳動脈基部 $\left(\mathrm{M}_{1}\right)$ も しくは内頸動脈（ 1 例は $\mathrm{C}_{5}, 1$ 例は $\left.\mathrm{C}_{6}\right)$ の閉塞 之前交通動脈の不全(狭窄), 側副路の形成の不全 を認めた。

7. てんかんの合併は, 遅延 Wernicke-Mann 型，低緊張型にのみ発生している。 その初発は卒 中発作後 3 か月から 15 か月の間である.この 2 型に打壮るてんかんの出現率は, 他の型に比して 1\%の危険率で有意である.

8. 上肢の筋力を十分な治療を行なった後, 肩 甲筋群, 屈筋群, 伸筋群に分けて, 各群の筋力の 平均と標準偏差を求めた（表 4 ）. 
表 3 皮質共存障害の各型への合併

\begin{tabular}{|c|c|c|c|c|c|c|c|c|c|c|}
\hline \multirow{2}{*}{ 型 } & \multicolumn{5}{|c|}{ 右片麻瘦 } & \multicolumn{5}{|c|}{ 左片麻痺 } \\
\hline & 例数 & 失語 & 失認 & 痴呆 & てんかん & 例数 & 失語 & 失認 & 痴呆 & てんかん \\
\hline 橋延䯣小脳症候群 & 2 & & & & & 1 & & & & \\
\hline 視床基底核症候群 & 10 & & & & & 8 & & & & \\
\hline 限局性皮質症候群 & 2 & 2 & & & & 2 & & & & \\
\hline 強剛型 & 4 & 2 & & & & 5 & 2 & 2 & & \\
\hline 即時 Wernicke-Mann 型 & 23 & 2 & & & & 23 & & & & \\
\hline 遅延 Wernicke-Mann 型 & 8 & 6 & & 2 & & 5 & & & & 1 \\
\hline 低緊張型 & 86 & 28 & 7 & 1 & & 74 & 2 & 4 & 8 & 2 \\
\hline 㖶延無緊張型 & 4 & 4 & 3 & & & 3 & 1 & 2 & 2 & \\
\hline 分類不能型 & 15 & & & & & 12 & & & & \\
\hline
\end{tabular}

表 4 Muscle Strength of Upper Extremity After Sufficient Treatment

\begin{tabular}{lccc}
\hline \multicolumn{1}{c}{ Type } & Scapular & Flexors & Extensors \\
\hline Prolonged atonic & $0.000 \pm 0.000$ & $0.000 \pm 0.000$ & $0.000 \pm 0.000$ \\
Hypotonic & $1.7789 \pm 1.140$ & $1.7142 \pm 1.0543$ & $1.3452 \pm 1.1982$ \\
Delayed W-M & $1.8412 \pm 0.9740$ & $1.7698 \pm 0.9984$ & $1.3403 \pm 1.1534$ \\
Immediate W-M & $2.9327 \pm 0.7017$ & $2.7731 \pm 0.6140$ & $2.5588 \pm 0.9216$ \\
Rigidity & $0.1143 \pm 0.1430$ & $0.0857 \pm 0.1201$ & $0.1000 \pm 0.1273$ \\
Ponto-bulbo-cerebellar & $3.1142 \pm 0.9150$ & $2.9523 \pm 1.1466$ & $2.9500 \pm 1.0828$ \\
Thalamo-basal ganglia & $3.2285 \pm 0.7711$ & $3.3357 \pm 0.9879$ & $2.8625 \pm 0.9303$ \\
Circumscribed cortical & $3.2381 \pm 1.2472$ & $3.4286 \pm 1.4142$ & $2.9500 \pm 1.0828$ \\
\hline
\end{tabular}

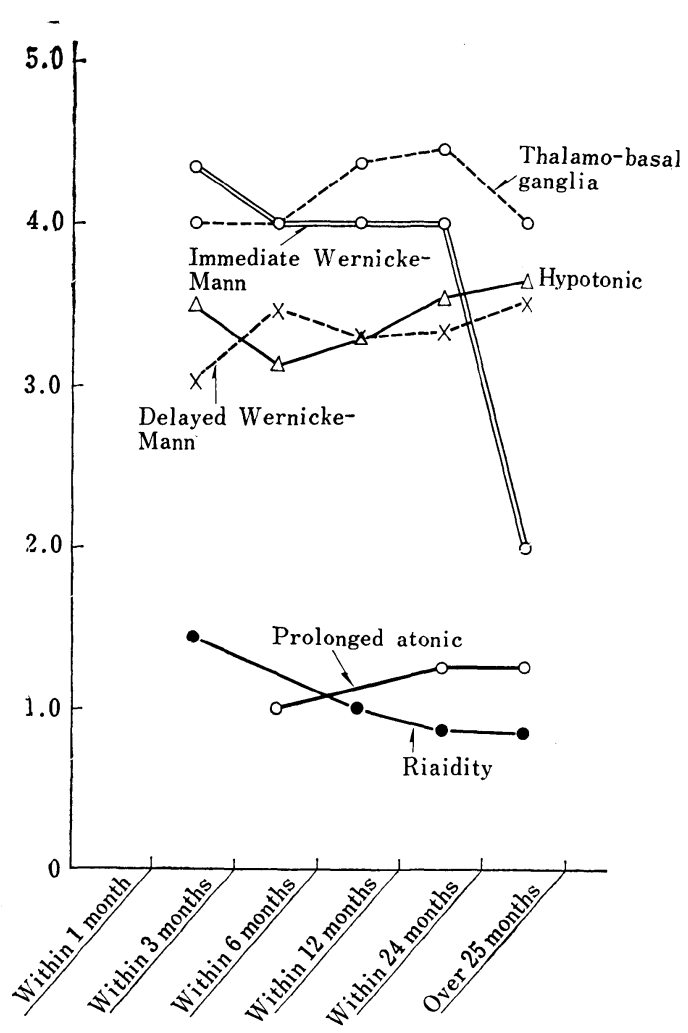

図 4 大腿四頭筋筋力経過図 a ．遷延無緊張型はいずれの群もまったくゼロであ る.

b . 低緊張型と遅延 Wernicke-Mann 型は外見上 差異があるにかかわらず, 筋力の平均, 偏差とも きわめて近似している. しかしどの筋群も2 2 以下 の回復にとどまる.

c. 即時 Wernicke-Mann 型は 錐体路障害を有す る群のらちで最良の回復を示す.

$\mathrm{d}$. 強剛型の筋力の回復は著しく悪い.

e . 橋延髄小脳症候群と限局性皮質症候群は錐体路 の犯され方が種々であるので，筋力の回復はよい が，偏差が大きい。

9. 下肢の筋力の代表として，大腿四頭筋の筋 力を測定し, 治療を加えない，入院時の測定值を 比較した（図 4 ）。発作後 1 か月，3 か月，6 力月， 1 年, 2 年およびそれ以上と区分すると，遷延無 緊張型と強剛型が著しく悪く，低緊張型と遅延 Wernicke-Mann 型は 3 前後の筋力を保有し, 視床基底核症候群と即時 Wernicke-Mann 型は 4 前後の筋力を有している. しかしこの 2 者は 2 年を越えると筋力の低下が見られる.

10. 骨多孔症, 肩手症候群の合併は遷延無緊張 型の 7 例中 6 例, 低緊張型 137 例中約半数が羅患 した。ただし後者は早期に治療を加えたものは， 
表 5 到達目標と訓練期間 (カッコ内は平均月数)

\begin{tabular}{|c|c|c|c|c|c|c|}
\hline 型 & 総 数 & $\begin{array}{l}\text { 步行不能 } \\
\text { (入院時) }\end{array}$ & $\begin{array}{l}\text { 步行不能 } \\
\text { (退院時) }\end{array}$ & $\begin{array}{l}\text { 長下肢装 } \\
\text { 具步行 }\end{array}$ & $\begin{array}{l}\text { 短下肢装具 } \\
\text { または手術 } \\
\text { 後步行 }\end{array}$ & 独 歩 \\
\hline 橋延䯣小脳症候群 & 3 & 3 & $2(3)$ & & $1(4)$ & \\
\hline 視床基底核症候群 & 18 & 0 & & & & \\
\hline 限局性皮質症候群 & 4 & 1 & & & $1(0.5)$ & \\
\hline 強剛型 & 9 & 9 & 1 & & $8(7.2)$ & \\
\hline 即時 Wernicke-Mann 型 & 48 & 14 & & & $7(1.8)$ & $7(1.4)$ \\
\hline 遅延 Wernicke-Mann 型 & 13 & 4 & & & $4(2.4)$ & \\
\hline 低緊張型 ～～～～～～～～～～～型 & 137 & 64 & & $14(3.1)$ & $47(4.2)$ & $3(3.4)$ \\
\hline 遷延無緊張型 & 7 & 7 & & $7(6.7)$ & & \\
\hline
\end{tabular}

備考 訓練月数からは, 手術臥床期間を減じてある.

病像が完成せず治瘾したので, 正確に計算しえな かった。

11. 到達目標, 治療に要する月数

日本のリハビリテーションの現状では，歩行不 能の状態で入院という場合も, むしろ絶対安静を 強制させられた一時的な無活動萎縮である場合が 多く，このような例を除外すると，実際に歩行不 能の例は表 5 に示すごとくである，ここで歩行と は distant supervision で独歩しうる程度をい い，歩行距離は $30 \mathrm{~m}$ 以上とする.

成績からは，遷延無緊張型が全例長下肢装具の 装用を必要とし，かなりの長期間の訓練を必要と したことが注目される。また強剛型のうち，手術 も装具も受け入れなかった 1 名, 橋延髅小脳症状 群の体幹失調の著しかった 2 名が歩行不能で終わ っている.

反対に視床基底核症候群は入院時歩行不能は 1 名もなかった。

なおこの表中には示さないが，屋外，屋内とも 杖使用を必要としないものは $38.2 \%$ ，いずれかで 杖を使用するものは $24.6 \%$ であった。

また強剛型, 遷延無緊張型の歩行パターンは, 安定ではあっても異常パターンを示した。

12. 一般に筋力の回復と日常生活動作の回復は 平行するが，視床基底核症候群においては運動調 節の障害のため, 筋力の回復はよくても日常生活 動作は score がよくならない。すなわち病型に より評価および訓練方法は異なるべきである.

\section{考 按}

脳卒中，片麻痷はきわめて頻度の高い疾患で知
らぬ者はいない。しかしその詳細が知られ，研究 されつくしているかといえば，むしろその原因論 についての探究は盛んであっても，現象面，およ び治療については意外に研究されていない.

その分類についても，定義を明らかにしえない ままに, 媛性, 弛緩性といら形容を冠して分類に 代用しているのが実情である。しかし Clemm$\operatorname{sen}^{21}$ も指摘するごとく, 痤性という概念には混 乱があり，個々の筋についてその有無を論ずるこ とはできても，片麻痺の全体について痙性を論議 することは当をえておらず，錐体路の障害があれ ば痙性があるのが当然であって，弛緩性麻㾝なる ものが中枢神経障害の中に存在するということは 不合理を感ぜざるを得ない。また弛緩性という言 葉は高緊張性, hypertonic といら言葉に対応 する言葉であると考えられ，少なくも，“急激な筋 の伸張に対する相動性反応の立進”としての病性 に対応する言葉ではない。

しかし実際には筋緊張が正常以下に著しく低下 している片麻痺が数多く存在することは事実であ り，しかもこのよらな片麻疩でも大腿四頭筋，下 腿三頭筋，指屈筋などには明らかな㾏性を見るの が常である。すなわち，片麻㾇に沶いては筋緊張 の異常（六進も低下もありらる）之痙性の六進が モザイク状に混在しており，一方で筋の随意性の 低下ないし消失といら，本来の片麻痻の病像がそ の基礎にあるのである，その上に，やや長期の経 過の内には筋の真性の短縮がこれに加わって全体 の病像の理解をますます困難ならしめる.

ここに提示した分類は純粋に臨床上患者の治療 に役だてることを目的として，現象面から患者の 
病像の理解をしよ5と試みたもので，病巣を厳密 に推定しょうという意図をもっていない，もとよ り臨床分類は人為的な区分であり, 病巣の局在, 性質，広がりといらものはこのような区分に制約 されないから, 個々の症例は移行, 重なり合いが 存在するのが当然である。ささらに脳の損傷の場合 は, Diaschisis や Vicarious function あるい は瘢痕形成による刺激の発生などの複雑な現象が からみ合らので，このような臨床分類が完全なも のでありらる可能性はないのではなかろらか.

この分類において, 各型の頻度は都会から遠く 離れたリハビリテーション病院入院患者という特 殊性を持っており，一般地域病院においては，こ れと異なる頻度を示すことは疑う余地がない，特 に外来患者を対象とするときは, 視床基底核病変 による，しびれを主訴とする不全片麻㾇患者の頻 度が著しく多いことを予想できる．しかし片麻瘏 のリハビリテーションを目的として入院した患者 の型別頻度は, 著者の経験では略この程度であっ た.すなわち入院患者においては低緊張型が約半 数であるという点は, 地域, 病院の種別にかかわ らず相等しい傾向である。

従来成書に記載されていたところと異なり，片 麻㾇の内約 $20 \%$ は発作初期から強い病性々強制 姿勢を示す，といらことは著者が新知見としてと り上げたいところである。しかも同様な強制姿勢 を初期からとりつづけながら, 治瘾しやすい即時 Wernicke-Mann 型が大部分を占めるが，きわ めて治癒しがたい強剛型が少数ではあるが存在す ることは注意すべき事実である。

即時 Wernicke-Mann 型が脳出血後の片麻痺 に多く見られるということは臨床的直観から考え られたが，推計学的には有意の差とならず，さら に例数を集めて検討することとしたい.

これに対して低緊張型が脳血栓に多いというこ とは $1 \%$ 危険率で有意の差があり, 明らかであ る. また遷延無緊張型と脳血栓との関係も同様で あり,このよらな重症の片麻痺のほとんどすべて が認むざき昏睡なしにきていることは，昏睡と片 麻痺の治痛しがたさとは無関係といえるであろ $\zeta$.

共存障害のらちで特に注目をひくのが，てんか
んと片麻癘の型との関係であり, 遅延 WernickeMann 型と，低緊張型とが特に強い相関を持っ ていることは，スクリーニングの指標として重要 であり，この 2 型には脳波検査が特に数か月から 1 年 6 か月までの間必要であるよらに考えられ る.

遷延無緊張型と皮質症候との関倸は, 脳血管写 の結果から見れば当然ともいえる.

臨床分類の最大の目的は, 回復可能性の予測と 治療方針の決定である．表 5 において見たごと く，片麻㾇にもきわめて治療しやすいものと，き わめて治癒しがたいもの, その中間に種々の病態 が存在しらる。そしてどの群, 型に属するかを診 断すれば，おおよその治療に要する月数，難易， 治療に必要な装具などは予測しうるのである.こ の点て臨床分類がリハビリテーションに益するこ と大きい.

この研究と平行して, 東大整形外科教室と協力 して片麻疸下肢の機能再建に関する研究を行ない つつあり, 尖足に対しては下腿三頭筋腱剝離形成 を主として行なっている。しかし内反をきたす要 素には種々の筋の関与があり, 前脛骨筋, 後脛 骨笳, 長指屈筋, 長母指屈筋が, 上述の病型とぞ のような関連を持って内反要素となっているかを 追究すべきであろらと考えているが，結論に達す るには時日を要するであろら，現在明らかなこと は, 強剛型, 真性の下腿三頭筋短縮は手術の絶対 適応で，他によい治療はありえないことである。

\section{結＼cjkstart語}

脳卒中後の片麻痷はきわめて多くの要素を含ん だ病態であるが，痤性をパラメーターとして，そ の分布, 強度, 時間的経過により分類すると, 次 のようになる.
A．初期から強制姿勢と病性を示すもの 強剛型
即時 Wernicke-Mann 型
B. 初期には弛緩姿勢を示すもの
遅延 Wernicke-Mann 型
低緊張型
遷延無緊張型

また病巣の明らかな次の 3 症候群を加えて $8 つ$ の病型が分類できる。 


\section{橋延髅小脳症候群}

視床基底核症候群

限局性皮質症候群

以上の各型はそれぞれ特徵を有し，予後の予 測, 治療法の選択に有用であり, リハビリテーシ ョンにおいては特に応用の道が広いと思われる。

稿を終えるにのぞえで恩師大島良雄教授のご指導ご校 閲を感謝する.また前長野県厚生連鹿教湯温泉療養所長 福井图彦博士および七沢病院長横山蟋博士のご指導とご 協力に感謝する。この論文の要旨は第 5 回国際物理医学 会 (1968.8. カナダモントリオール) で報告した。

\section{Reference}

1) Phelps, W.M. : Etiology and Diagnostic Classification of Cerebral Palsy, In Procedings of the Cerebral Palsy Institute, Association for Aid of Crippled Children Inc, New York, 1950.

2) Schuell, H. Aphasia in Adults : Hoeber Medical Division, New York, 1964.

3) Rusk, H. A. : Rehabilitation Medicine, 590, 1964, C.V. Mosby, Saint Louis, 1964.

4) Brunnstrom, S. : Motor Testing Procedures in Hemiplegia, J. of Am. Phys. Ther., 49, 357, 1966.

5) Treanor, W. J. : Potential Reversibility of the Hemiplegic Posture, Am. J. of Cardiology, 7, 370, 1961.

6) Twitchel, T.E. : The Restoration of Motor Function Following Hemiplegia in Man, Brain, 74, 443, 1951.

7) Twitchel, T. E. : Attitudal Reflexes, J. Am. Phys. Ther. Ass., 45, 411, 1965.

8) Hasting, A.E. : Patterns of Motor Function in Adult Hemiplegia, Archives of Phys. Med.
\& Reh., 46, 265, 1965.

9) Pesczynski, M. : Therapeutic Exercise ; Exercise for Hemiplegia, E. Licht Libraries, 3, 739, 1961.

10) Pesczynski, M. : Rehabilitation and Medicine, Rehabilitation of Hemiplegia, E. Licht Libraries, New heaven Conn, 10, 401, 1968.

11) Granit, R. : Nobel Symposium L, Muscular Afferent and Motor Control, John Willey \& Sons, New York, 1966.

12) Yahr, M. D. and Purpura, D. P. : Neurophysiological Basis of Normal and Abnormal Motor Activity, Raven Press, New York, 1967.

13) Cooper I. : Involuntary Movement Disorders, Hoeber, New York, 1969.

14) Costa, L. J. and Yahr, M. D. : Biochemistry and Pharmacology of the Basal Ganglia, Raven Press, New York, 1967.

15) Kennard, S. and Fulton, J. F. : The Localizing Significance of Spasticity, Reflex Grasping and The Signs of Babinski and Rossolimo, Brain, 56, 213, 1933.

16) Critchley, M. : The Parietal Lobes, Hafner, New York, 1966.

17) 大橋博司: 臨床脳病理学, 医学書院, 東京, 1963.

18）井村恒郎：精神医学研究，1，2， みすよ゙書房, 東京, 1967,68 .

19) 相沢豊三: 脳卒中, 南江堂, 東京, 1963.

20）花籠良一，ほか：脳卒中のリハビリテーション と脳血管写所見，脳血管閉塞の側副血行路とリ ハビリテーション, リハビリテーション医学, 7, 159, 1970.

21) Clemmsen, S. M. : The Horowitz Lectures, Spasticity and Rigidity, New York Univ. Medical Center, New York, 1960.

\section{お知らせ}

\section{第 6 回日本パラプレジア医学会ご案内}

\begin{tabular}{|c|c|c|}
\hline 会 & 期 & 昭和 46 年 9 月 5 日（日） \\
\hline 会 & 場 & 仙台市・仙台ホテル \\
\hline 主 & 題 & 1) 脊損患者の腎障害とその対策 \\
\hline & & $\begin{array}{l}\text { 司会 熊大泌尿器科 池上 奎一教 } \\
\text { 2) 替髄挰傷患者の裖創対策 }\end{array}$ \\
\hline & & $\begin{array}{l}\text { 司会 東大整形外科 津山 直一教 }\end{array}$ \\
\hline & 演 : 甹 & 它全脊髄横断修復への試み \\
\hline & & 東北大脳神経外科 鈴木 二郎教授 \\
\hline & 边み & $\begin{array}{l}\text { 演題名, 所属, 氏名および講演抄録 } \\
\text { (結論)を } 400 \text { 字詰原稿用紙 } 1 \text { 枚以内 }\end{array}$ \\
\hline
\end{tabular}

（Ｂ５版）に書き込んで，会長あて書 留便でお送りください。なお採用の可 否については会長にご一任ください. また抄録集は 7 月末日ごろにお送りし ます。.

申込期限 7 月 15 日必着

送 り先 仙台市星陵町 1-1 ( $\mathbf{T} 780$ )

東北大学医学部泌尿器科学教室 第 6 回日本パラプレジア医学会 会長 宍戸 仙太郎 